\title{
Evaluasi Implementasi Kurikulum 2013 di Tingkat SLTA di Kabupaten Pringsewu Menggunakan Model CIPP
}

\author{
Trisnawati1, Leni Anggraeni2, Arief Budi Wicaksono2 \\ 1 Program Studi Sistem Informasi, STMIK Pringsewu Lampung \\ 2 Program Studi Pendidikan Matematika, Universitas Tidar \\ *Coresponding author: trisnawatistmikpsw@gmail.com
}

\section{ART I CLE INFO}

Article history:

Received: 24 Mei 2019

Accepted: 12 September 2019

\section{Keywords:}

Evaluasi, Kurikulum 2013, CIPP, SMA/SMK/MA

\begin{abstract}
ABSTRAK
Kurikulum merupakan acuan bagi segala bentuk aktivitas pembelajaran guna mencapai tujuan pendidikan. Oleh karena itu penyempurnaan kurikulum pada setiap jenjang pendidikan termasuk di tingkat SMA menjadi satu hal yang mutlak harus dilakukaan oleh pemerintah. Dalam implementasinya, kurikulum perlu dievaluasi agar diketahui kesesuaian maupun permasalahan yang muncul dalam pelaksanaannya. Penelitian ini merupakan penerapan model Contexs, Input, Process, Product (CIPP) untuk mengetahui sejauh mana implementasi kurikulum 2013 di tingkat SMA di kabupaten Pringsewu. Ketercapaian implementasi yang dimaksud dalam penelitian mengacu pada keputusan Permendikbud RI Nomor 81 A tahun 2013 tentang Implementasi kurikulum 2013. Hal ini penting dilakukan karena kurikulum 2013 diterapkan di seluruh Indonesia sehingga diharapkan hasil penelitian ini akan menjadi masukan yang objektif untuk pihak sekolah, siswa, orang tua, maupun pemerintah tentang pelaksanaan kurikulum 2013. Masukan inilah yang bisa dijadikan acuan untuk perbaikan pelaksanaan kurikulum pada khususnya dan kemajuan dunia pendidikan pada umumnya. Berdasarkan hasil penelitian mengenai evaluasi implementasi kurikulum 2013 di tingkat sma/smk/ma sederajat di kabupaten pringsewu menggunakan model CIPP dapat disimpulkan implementasi kurikulum 2013 di tingkat SMA/SMK/MA sederajat di kabupaten pringsewu sudah berjalan dengan baik, tetapi aspek sarana prasarana, proses pembelajaran dan proses penilaian masih perlu penyempurnaan.
\end{abstract}

\section{PENDAHULUAN}

Pendidikan merupakan salah satu bidang yang ikut menentukan kemajuan suatu bangsa. Dari bidang pendidikan inilah diharapkan akan terlahir generasi bangsa yang 
cerdas, terampil, berakhlak baik dan berwawasan luas. Keberhasilan pendidikan harus didukung oleh sistem pendidikan nasional yang relevan dengan jamannya. Salah satu yang menjadi indikator keberhasilan pendidikan adalah kurikulum. Oleh karena itu penyempurnaan kurikulum pada setiap jenjang pendidikan baik tingkat SD, SMP, dan SMA menjadi satu hal yang mutlak harus dilakukaan oleh pemerintah. Menurut Nasution (2008:5) Kurikulum merupakan acuan bagi segala bentuk aktivitas pembelajaran guna mencapai tujuan pendidikan.[1]

Di Indonesia sudah beberapa kali terjadi perubahan kurikulum. Tercatat sejak tahun 1945, kurikulum 10 kali berubah, yaitu pada tahun 1947, 1952, 1964, 1968, 1975, 1984,1994, 2004, dan 2006, disusul dengan kurikulum terbaru dan sedang diterapkan saat ini yaitu kurikulum 2013. Pada kurikulum 2013 akan dirampingkan dalam hal jumlah mata pelajaran. "Struktur kurikulum terdiri atas sejumlah mata pelajaran, beban belajar, dan kalender pendidikan" (Permendikbud, 2013). [2] Meskipun sudah diterapkan selama kurang lebih 4 tahun bukan berarti kurikulum ini sudah berhasil diimplementasikan secara menyeluruh di sekolah-sekolah. Keberhasilan implementasi kurikulum dipengaruhi oleh berbagai komponen. Komponen sekolah terdiri atas guru, kepala sekolah, fasilitas, budaya, lingkungan. Semua komponen tersebut memiliki peran masingmasing dalam penerapan kurikulum baru (Katuuk, 2014). [14]

Kurikulum 2013 merupakan penyempurnaan dari kurikulum-kurikulum sePringsewumnya. Oleh karena itu dapat dipastikan isinya juga sudah dikaji dan dirancang dengan sangat baik. Akan tetapi bukan berarti kurikulum tersebut sudah sempurna dan dapat diimplementasikan dengan baik. Allan Ornstein dan Francis Hunkins (2004:298) bahwa "suatu kurikulum baru yang baik secara ilmiah Pringsewum tentu dapat dilaksanakan, atau akan tumpul keilmiahannya di depan pintu ruang kelas".[3] Hal inilah yang menjadi dasar diperlukannya evaluasi kurikulum 2013. Evaluasi ini dilakukan untuk mengetahui sejauh mana implementasi kurikulum dan permasalahan di dalamnya.

Penelitian ini merupakan evaluasi untuk mengetahui sejauh mana implementasi kurikulum 2013 di tingkat SMA di kabupaten Pringsewu dengan menggunakan model Contexs, Input, Process, Product (CIPP). Hal ini penting dilakukan karena kurikulum 2013 diterapkan di seluruh Indonesia sehingga diharapkan hasil penelitian ini akan menjadi masukan yang objektif untuk pihak sekolah, siswa, orang tua, maupun pemerintah tentang pelaksanaan kurikulum 2013. Masukan inilah yang bisa dijadikan acuan untuk perbaikan pelaksanaan kurikulum pada khususnya dan keemajuan dunia pendidikan pada umumnya. Model CIPP dipilih karena model evaluasi ini bisa mencakup semua aspek implementasi kurikulum kurikulum 2013.

Berdasarkan uraian di atas maka perlu dilakukan penelitian tentang implementasi kurikulum 2013 tingkat SMA sederajat di Kabupaten Pringsewu dengan menggunakan model CIPP. Ketercapaian implementasi yang dimaksud dalam penelitian mengacu pada keputusan Permendikbud RI Nomor 81 A tahun 2013 tentang Implementasi kurikulum 2013.

\section{TINJAUAN PUSTAKA \\ Penelitian Terdahulu}

Penelitian yang dilakukan oleh Mizan Abrory dan Badrun Kartowagiran, hasil penelitian implementasi kurikulum 2013 yaitu, kualitas perencanaan silabus dan RPP pada pembelajaran kategori baik, kualitas pelaksanaan pembelajaran pada kegiatan pendahuluan, kegiatan inti, dan kegiatan penutup termasuk kategori kurang baik, kualitas penilaian pem-belajaran termasuk pada kompetensi sikap, kompetensi pengetahuan, dan kompetensi pengetahuan termasuk kategori kurang baik. Kemudian penelitian yang dilakukan oleh Meiana Yurike Dewi, hasil penelitian menunjukkan guru mata pelajaran Bahasa Indonesia SMA Negeri Kabupaten Bantul mengimplementasikan Kurikulum 2013; tanggapan guru terhadap Kurikulum 2013 adalah kurikulum yang bagus dan ideal, 
namun mendadak dan kurang persiapan; kendala dalam implementasi Kurikulum 2013 adalah keterbatasan waktu, keterbatasan sarana dan prasarana, penilaian, dan kekativan peserta didik dalam proses belajar mengajar; guru mengatasi kendala implementasi Kurikulum 2013 dengan memberikan tugas rumah, mengadakan penilaian secara kelompok, menyelesaikan administrasi guru di rumah, menggunakan media yang ada dan melengkapi sendiri, memberikan motivasi dan rangsangan berupa pemberian pujian dan penambahan nilai bagi peserta didik, penilaian dilakukan berkala dan menggunakan forum MGMP sebagai tempat bertukar informasi. Dari penelitian yang pernah dilakukan, Pringsewum pernah ada yang menerapkan model Contexs, Input, Process, Product (CIPP) untuk mengevaluasi implementasi kurikulum 2013 tingkat SMA/SMK/MA sederajat di Kabupaten Pringsewu Lampung.

\section{Implementasi Kurikulum 2013 (K-13)}

Berdasarkan Permendikbud nomor 81 A tentang implementasi kurikulum 2013, kurikulum 2013 diterapkan di Indonesia mulai tahun ajaran 2013/2014. K-13 merupakan langkah lanjutan dari KTSP yang mencakup aspek sikap, pengetahuan dan keterampilan secara terpadu. Implementasi kurikulum adalah kegiatan mempraktikkan/menerapkan suatu ide, program atau seperangkat kegiatan baru untuk individu atau organisasi yang menjalankan kurikulum. Hal ini sesuai dengan pendapat Majid (2014) yang menyatakan bahwa "implementasi kurikulum merupakan operasionalisasi konseep kurikulum yang masih bersifat potensial (tertulis) menjadi aktual dalam kegiatan pembelajaran.[5] Implementasi kurikulum mencakup tiga kegiatan pokok yaitu pengembangan program, pelaksanaan pembelajaran dan evaluasi pembelajaran (Kunandar, 2011).[6]

\section{Kurikulum 2013 untuk SMA}

Dalam kurikulum2013 (K-13) untuk tingkat SMA, terdapat 3 kelompok mata pelajaran yaitu kelompok A, B, dan C. Kelompok A terdapat mata pelajaran Pendidikan Agama, Pendidikan Pancasila dan Kewarganegaraan, Matematika, Sejarah Indonesia dan Bahasa Inggris. Kelompok B terdiri dari mata pelajaran Seni Budaya, Pendidikan Jasmani Olahraga dan Kesehatan, serta Prakarya. Kelompok C disebut juga mata pelajaran peminatan. Mata pelajaran yang termasuk dalam kelompok ini untuk Peminatan akademik Matematika dan Sains adalah Matematika, Biologi, Fisika dan Kimia. Adapun untuk kelompok peminatan Sosial adalah Geografi, Sejarah, Ekonomi, Sosiologi dan Antropologi). Mata pelajaran dalam Peminatan Bahasa adalah Bahasa dan Sastra Indonesia, Bahasa dan Sastra Mandarin, Bahasa dan Sastra Inggris, serta Bahasa dan Sastra Arab. Ada juga mata pelajaran pilihan yang terdiri dari bahasa asing lain, literasi media teknologi terapan dan lainnya.

Seluruh siswa wajib mengikuti mata pelajaran kelompok A dan B serta memilih salah satu kelompok $\mathrm{C}$ (peminatan). Waktu pembelajaran yang ditempuh adalah 18 jam untuk pelajaran wajib, 16 jam untuk mata pelajaran peminatan dan 6 jam untuk mata pelajaran lintas minat, pelajaran pilihan maupun mata pelajaran pilihan tambahan dari sekolah.(Dokumen K-13)[7]

\section{Evaluasi Kurikulum 2013}

Evaluasi memegang peranan penting dalam penerapan kurikulum 2013. Melalui evaluasi ini, keberhasilan dan tingkat ketercapaian program bisa diketahui. Hasil evaluasi juga bisa dijadikan acuan dalam menentukan kebijakan terkait tindak lanjut kurikulum tersebut karena melalui evaluasi bisa diketahui kondisi kurikulum dalam rancangannya, pelaksanaannya serta hasilnya. Evaluasi kurikulum dimaksudkan untuk memeriksa tingkat ketercapaian tujuan pendidikan yang ingin diwujudkan melalui kurikulum yang bersangkutan, indikator kerja yang akan dievaluasi yaitu efektivitas program (Syaodih, 2009).[8] 


\section{Model CIPP}

Model CIPP menggunakan 4 jenis evaluasi yaitu evaluasi konteks (contex), masukan (input), pelaksanaan (process), dan hasil (product). Adapun penjabaran dari setiap jenis evaluasi tersebut adalah sebagai berikut:

\section{Konteks (Contex)}

Unsur-unsur yang akan dievaluasi adalah sumber daya manusia, sarana dan prasarana, pemahaman guru mengenai K-13, pemahaman siswa tentang K-13 dan keterlibatan orang tua.

\section{Masukan (Input)}

Unsur-unsur yang akan dievaluasi adalah pengadaan buku, pelatihan guru dan kepala sekolah, pelaksanaan pembelajaran dan pelaksanaan pendampingan K-13.

\section{Proses (Process)}

Unsur-unsur yang akan dinilai adalah proses pembelajaran, proses penilaian dan manajemen pembelajaran.

4. Produk (Product)

Unsur-unsur yang akan dinilai adalah tanggapan responden mengenai implementasi

kurikulum 2013 dan strategi yang perlu disiapkan dalam implementasi kurikulum 2013. Menurut Hasan ( 2008: 222), secara keseluruhan prosedur lengkap evaluasi CIPP digambarkan sebagai berikut yang jelas menunjukkan langkah-langkah evaluasi dan fokus evaluasi secara keseluruhan :[9]

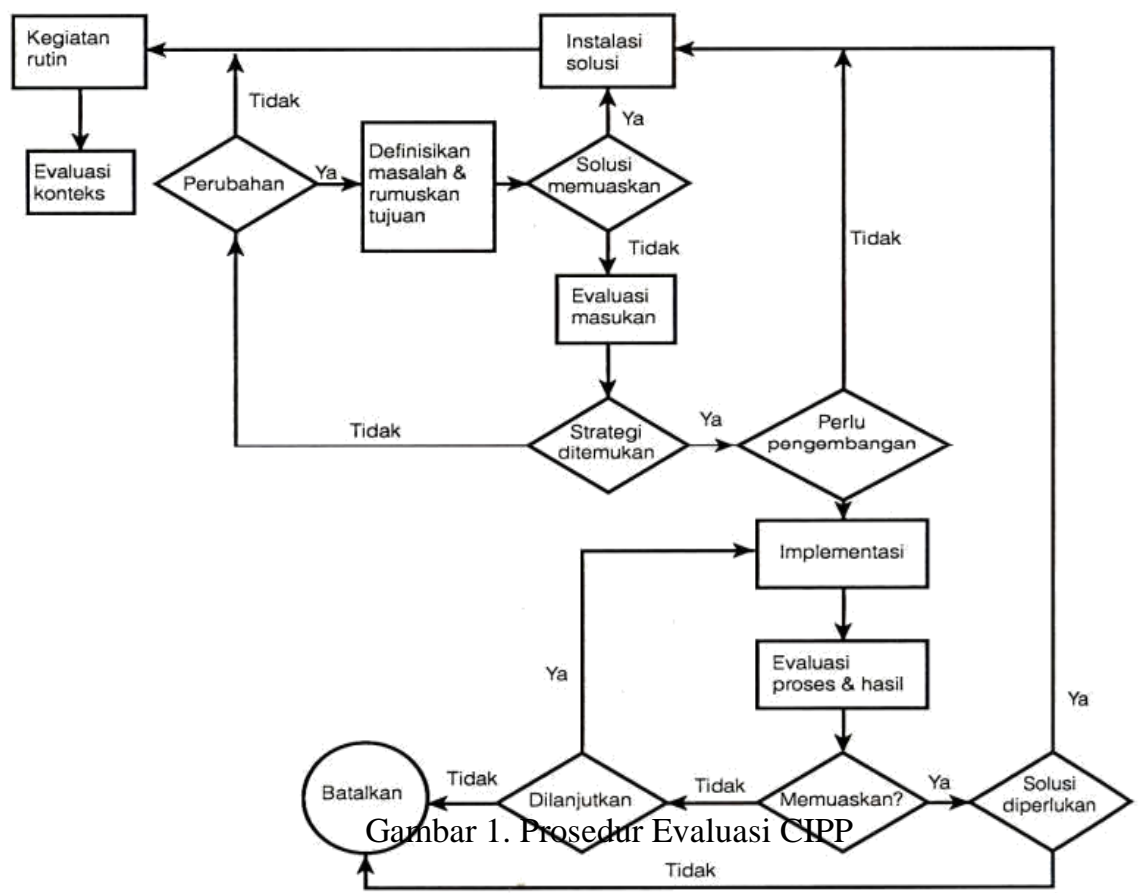

\section{METODE}

\section{a. Waktu dan Tempat Penelitian}

Penelitian ini akan dilakukan pada bulan Maret - April 2019, lokasi penelitian 
adalah SMA/ SMK sederajat di Kabupaten Pringsewu Lampung.

\section{b. Rancangan Penelitian}

\section{Jenis Penelitian}

Penelitian ini merupakan penelitian kualitatif deskriptif yaitu salah satu penelitian yang dilakukan dengan tujuan untuk mencari jalan keluar atau pemecahan masalah terhadap hal yang terjadi kemudian disajikan data dan analisa terhadap informasi yang dikumpulkan (Nazir, 2009)[10]

\section{Obyek Penelitian}

Obyek penelitian dapat dinyatakan sebagai situasi sosial penelitian yang ingin diketahui apa yang terjadi di dalamnya. Pada obyek penelitian ini, peneliti dapat mengamati secara mendalam aktivitas (activity) orang-orang (actors) yang ada pada tempat (place) tertentu (Sugiyono, 2007:215).[11] Obyek penelitian ini adalah pelaksanaan kurikulum 2013 tingkat SMA/SMK sederajat di kabupaten pringsewu lampung.

\section{Alat dan Bahan Penelitian}

Alat yang digunakan dalam penelitian ini antara lain camera digital, alat tulis, laptop, questioner penelitian dan kendaraan bermotor untuk mobilisasi.

\section{Populasi dan Sampel Penelitian}

Populasi adalah keseluruhan atau himpunan obyek maupun subyek dengan ciriciri yang sama (Singarimbun $d k k, 1989$ ). [12] Sampel adalah sebagian individu yang diselidiki dari keseluruhan individu penelitian. Sampel yang baik adalah yang mewakili populasi atau yang representatif artinya yang menggambarkan keadaan populasi atau mencerminkan populasi secara maksimal. Dalam penelitian ini populasinya adalah SMA/SMK sederajat di kabupaten pringsewu lampung sedangkan sampelnya adalah 10 SMA/SMK sederajat di kabupaten pringsewu lampung yang dipilih dari 9 kecamatan yang berbeda.

\section{c. Teknik Pengumpulan Data}

Pengumpulan data adalah prosedur yang sistematis dan standar untuk memperoleh data yang diperlukan (Nazir, 2005:74).[13] Dalam penelitian ini pengumpulan data dilakukan dengan observasi, pengisian angket, wawancara dan dokumentasi.

\section{d. Teknik Analisis Data}

\section{Data Kuatitatif}

Data-data kuantitatif yang diperoleh melalui pembagian angket/kuesioner akan dianalisis dengan metode deskriptif analitis dengan mencari deskriftif persentase. Data hasil deskriftif persentase akan dimasukkan ke dalam kategori jawaban agar diperoleh kesimpulan mengenai setiap aspek yang dianalisis. Adapun Kategori tingkat jawaban ditunjukkan pada tabel 1 berikut:

\begin{tabular}{|c|c|c|}
\hline No. & Tingkatan Jawaban & Kategori \\
\hline 1 & $76 \%-100 \%$ & Sangat Baik \\
\hline
\end{tabular}




\begin{tabular}{|c|c|c|}
\hline 2 & $51 \%-75 \%$ & Baik \\
\hline 3 & $26 \%-50 \%$ & Kurang baik \\
\hline 4 & $1 \%-25 \%$ & Tidak Baik \\
\hline
\end{tabular}

Tabel 1. Kategori Tingkat Jawaban Responden

\section{Data Kualitatif}

Data kualitatif diperoleh melalui wawancara dan dokumentasi. Data tersebut akan dianalisis dengan tahapan mereduksi data, display data dan penarikan kesimpulan.

\section{HASIL DAN PEMBAHASAN}

\section{Evaluasi Konteks (Contex)}

\section{a. Aspek Sarana dan Prasarana}

Kuesioner tentang sarana prasarana ini dibagikan kepada kepala sekolah, guru dan siswa. Berdasarkan hasil dari pembagian kuesioner kepada responden yang dilakukan di SMA/SMK/MA di Kabupaten Pringsewu, diperoleh data sebagai berikut:

Tabel 2. Hasil Kuesioner Aspek Sarana Prasarana

\begin{tabular}{|r|l|c|c|c|c|c|}
\hline No. & Responden & Jumlah & n & N & DP & Kategori \\
\hline 1 & Kepala Sekolah & 10 & 149 & 200 & $74.50 \%$ & Baik \\
\hline 2 & Guru & 30 & 434 & 600 & $72.33 \%$ & Baik \\
\hline 3 & Siswa & 50 & 797 & 1000 & $79.70 \%$ & Sangat Baik \\
\hline & Jumlah & 90 & & & $75.51 \%$ & Sangat baik \\
\hline
\end{tabular}

Berdasarkan data kuesioner, peneliti bisa mengatakan bahwa sarana prasarana di SMA/SMK/MA Kabupaten Pringsewu sudah sangat baik. Hal ini bisa dilihat pada tabel 2 di atas. Dalam tabel di atas tergambar jelas bahwa dari kuesioner yang dibagikan kepada responden, rata-rata yang diperoleh adalah $75,51 \%$. Skor terendah dari aspek sarana prasarana diperoleh dari pengisian kuesioner yang dilakukan oleh guru yaitu 72,33\% sedangkan skor tertinggi diperoleh dari kuesioner yang diisi oleh siswa yaitu 79,70\%. Akan tetapi berdasarkan hasil wawancara terhadap kapala sekolah dan guru di 2 sekolah swasta yang diteliti, kekurangan sarana prasarana seperti ketiadaan buku, kekurangan laboratorium dan kekurangan komputer menjadi kendala tersendiri dalam implementasi K-13 di sekolah tersebut.

\section{b. Aspek Pehamahaman Terhadap K-13}

Data mengenai pemahaman kepala sekolah dan guru tentang K-13 diperoleh melalui kuesioner dan wawancara yang dilakukan peneliti terhadap para responden.

Tabel 3. Hasil Kuesioner Aspek Pemahaman Terhadap K-13

\begin{tabular}{|r|c|c|c|c|c|c|}
\hline No. & Responden & Jumlah & n & N & DP & Kategori \\
\hline 1 & Kepala Sekolah & 10 & 162 & 200 & $81.00 \%$ & Sangat Baik \\
\hline
\end{tabular}




\begin{tabular}{|c|l|l|c|c|c|c|}
2 & Guru & 30 & 419 & 600 & $69.83 \%$ & Baik \\
\hline & Jumlah & 40 & & & $75.42 \%$ & Sangat Baik \\
\hline
\end{tabular}

Berdasarkan data kuesioner pada tabel 3, peneliti bisa mengatakan bahwa Aspek Pemahaman Terhadap K-13 oleh kepala sekolah dan guru di SMA/SMK/MA Kabupaten Pringsewu sudah sangat baik. Dari wawancara yang dilakukan peneliti mengenai pemahaman guru terhadap K-13 diperoleh penjelasan sebagai berikut:

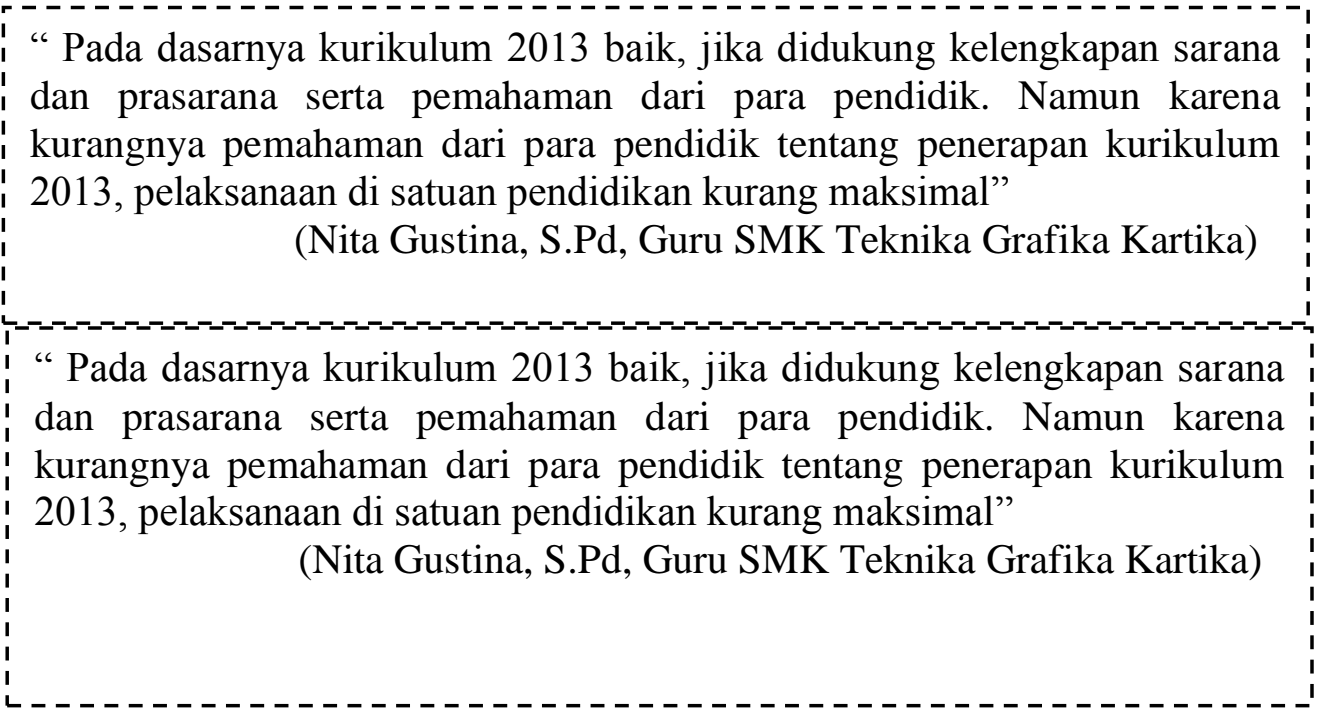

\section{Evaluasi Masukan (Input)}

\section{a. Aspek Ketersediaan Buku Pedoman Guru dan Siswa}

Evaluasi masukan (input) membantu mengatur keputusan, menentukan sumber-sumber yang ada, alternative apa yang diambil, apa rencana dan strategi untuk mencapai tujuan dan bagaimana prosedur kerja untuk mencapainya.

Berdasarkan hasil wawancara terhadap guru-guru di SMA/SMK/MA di Kabupaten Pringsewu, buku pedoman guru dan siswa sudah tersedia. Akan tetapi, di beberapa sekolah, ketersediaan buku pedoman guru dan siswa tersebut belum mencukupi untuk digunakan dalam proses belajar mengajar. Sehingga pihak sekolah memilih untuk menyediakan buku secara mandiri dalam hal ini dibeli sendiri di toko buku terdekat atau dengan mencetak Buku Sekolah Elektronik (BSE).

\section{b. Aspek Pelatihan dan Pendampingan}

Data mengenai pelatihan dan pendampingan guru diperoleh dari pembagian kuesioner dan wawancara dengan responden. Kuesioner dibagikan kepada kepala sekolah dan guru

Tabel 4. Hasil Kuesioner Aspek Pelatihan dan Pendampingan

\begin{tabular}{|r|l|c|c|c|c|c|}
\hline No. & \multicolumn{1}{|c|}{ Responden } & Jumlah & n & N & DP & Kategori \\
\hline 1 & Kepala Sekolah & 10 & 157 & 200 & $78.50 \%$ & Sangat Baik \\
\hline 2 & Guru & 30 & 424 & 600 & $70.67 \%$ & Baik \\
\hline & Jumlah & 40 & & & $74.58 \%$ & Baik \\
\hline
\end{tabular}

Mencermati data penelitian pada tabel 4 di atas dapat disimpulkan bahwa pelaksanaan pelatihan dan pendampingan terhadap guru dan kepala sekolah dari persepsi kepala sekolah berjalan dengan sangat baik yaitu sebesar 78,50\%. Sedangkan menurut pendapat dan persepsi para guru, pelatihan berjalan baik dengan 
persentase yang diperoleh sebesar 70,67\%. Berdasarkan hasil wawancara yang dilakukan peneliti mengenai aspek pelatihan dan pendampingan yang diberikan kepada para guru sudah berjalan dengan baik.

\section{c. Aspek Manajemen Pembelajaran}

Evaluasi kegiatan manajemen pembelajaran yang dilakukan di Kabupaten Pringsewu terdiri dari 7 indikator, yaitu: Penyesuaian jadwal pelajaran dengan struktur kurikulum, Penetapan peminatan siswa, Penempatan guru yang mata pelajarannya tidak tercantum dalam struktur K-13 dan mata pelajaran baru, Penyesuaian penyusunan jadwal pelajaran dengan ketersediaan fasilitas (jumlah, jenis, dan kualitasnya), Penyesuaian jumlah dan beban tugas mengajar guru, Kesesuaian jumlah dan waktu penerimaan buku, dan Dukungan fasilitas dalam pelaksanaan pembelajaran hampir semua sudah terlaksana.

Tabel 5. Hasil Kuesioner Aspek Manajemen Pembelajaran

\begin{tabular}{|r|l|c|c|c|c|c|}
\hline No. & \multicolumn{1}{|c|}{ Responden } & Jumlah & n & N & DP & Kategori \\
\hline 1 & Kepala Sekolah & 10 & 228 & 280 & $81.43 \%$ & Sangat Baik \\
\hline & Jumlah & 40 & & & $81.43 \%$ & Sangat Baik \\
\hline
\end{tabular}

Dari ketujuh indikator tersebut didapatkan rata-rata persentase skor sebesar $81,43 \%$ yang berarti bahwa aspek manajemen pembelajaran di sekolah sudah melaksanakan K-13 dengan sangat baik. Hasil ini menunjukkan bahwa sekolah sudah berusaha dengan baik untuk mengatur segala aktivitas pembelajaran agar sesuai dengan K-13 walaupun masih ada kekurangan di beberapa hal yang berada di luar kuasa sekolah untuk menanganinya seperti buku pedoman guru dan buku pelajaran siswa dan ketersediaan fasilitas pendukung pemebelajaran.

\section{d. Aspek Layanan Kesiswaan}

e.

Tabel 5. Hasil Kuesioner Aspek Layanan Kesiswaan

\begin{tabular}{|c|l|c|c|c|c|c|}
\hline No. & Responden & Jumlah & n & N & DP & Kategori \\
\hline 1 & Siswa & 50 & 848 & 1200 & $70.67 \%$ & Baik \\
\hline & Jumlah & 50 & & & $70.67 \%$ & Baik \\
\hline
\end{tabular}

Rata-rata skor dari keenam indikator tersebut sebesar 70,67\%, sehingga dapat disimpulkan bahwa layanan kesiswaan di ketujuh sekolah SMA/SMK/MA di Kabupaten Pringsewu terlaksana dengan baik. Harapannya layanan kesiswaan terus ditingkatkan kualitasnya agar dapat digunakan sebagaimana mestinya dan tidak menyulitkan berbagai pihak.

\section{Evaluasi Proses}

\section{a. Aspek Proses Pembelajaran}

Persepsi guru terhadap proses belajar mengajar K-13 diperoleh hasil yang sangat baik. Data yang diperoleh dari hasil analisis kuesioner dapat dilihat pada tabel 6 berikut:

Tabel 6. Hasil Kuesioner Aspek Proses Pembelajaran

\begin{tabular}{|c|l|c|c|c|c|c|}
\hline No. & Responden & Jumlah & n & N & DP & Kategori \\
\hline 1 & Kepala Sekolah & 10 & 151 & 200 & $75.50 \%$ & Sangat Baik \\
\hline 2 & Guru & 30 & 409 & 600 & $68.17 \%$ & Baik \\
\hline
\end{tabular}




\begin{tabular}{|c|l|c|c|c|c|c|}
3 & Siswa & 50 & 473 & 1000 & $47.30 \%$ & Kurang Baik \\
\hline & Jumlah & 90 & & & $63.66 \%$ & Baik \\
\hline
\end{tabular}

Deskriftif Persentase yang diisi oleh kepala sekolah sebesar 75,50\%, guru sebesar $68,17 \%$ dan hasil persepsi siswa adalah $47,30 \%$. Setelah dilakukan wawancara terhadap siswa, rendahnya deskriptif persentase terhadap aspek proses pembelajaran ini disebabkan sulitnya siswa memahami materi karena harus belajar secara mandiri. Menurut mereka untuk beberapa materi, belajar mandiri tidak efektif karena nalar siswa terkadang tidak sampai sehingga mereka kesulitan memahami materi tersebut.

\section{b. Aspek Proses Penilaian}

Tabel 7. Hasil Kuesioner Aspek Proses Penilaian

\begin{tabular}{|c|l|c|c|c|c|c|}
\hline No. & Responden & Jumlah & n & N & DP & Kategori \\
\hline 1 & Kepala Sekolah & 10 & 153 & 200 & $76.50 \%$ & Sangat Baik \\
\hline 2 & Guru & 30 & 424 & 600 & $70.67 \%$ & Baik \\
\hline & Jumlah & 40 & & & $73.58 \%$ & Baik \\
\hline
\end{tabular}

Berdasarkan hasil perhitungan data kuesioner pada tabel 7 di atas, bahwa persentase persepsi guru tentang penilaian adalah 70,67\% merupakan kategori kurang baik. Sedangkan dari hasil olah data kuesioner yang dibagikan kepada kepala sekolah, persepsi aspek proses penilaian diperoleh hasil persentasenya sebesar 76,50\%. Rata-rata yang diperoleh dari pengisian kuesioner oleh kepala sekolah dan guru terkait aspek proses penilaian implementasi K-13 di tingkat SMA/SMK/MA di Kabupaten Pringsewu adalah 73,58\%. Hasil ini merujuk pada kategori baik pada aspek proses penilaian.

Dari hasil wawancara aspek penilaian menjadi kesulitan bagi beberapa guru dalam implementasi K-13 di tingkat SMA/SMK/MA Kabupaten Pringsewu. Alasannya adalah kurangnya pelatihan pada aspek penilaian dan format penilaian yang terlalu banyak dalam aplikasi penilaian. Proses penilaian dalam K-13 dirasakan lebih sulit dan rumit, namun banyak guru yang optimis dapat melaksanakan penilaian dengan baik.

\section{Evaluasi Keluaran (Product)}

Evaluasi proses diharapkan dapat membantu pimpinan atau guru untuk membuat keputusan yang berkenaan dengan kelanjutan, akhir, maupun modifikasi program Berkaitan dengan penelitian ini, evaluasi keluaran berupa tanggapan umum responden tentang implementasi K-13 di tingkat SMA/SMK/MA di Kabupaten Pringsewu. Sebagian besar responden yang diwawancara mengatakan bahwa kurikulum ini bagus karena ada penekanan pada karakter dan kemandirian siswa dan penekanan keaktifan siswa dalam proses belajar mengajar. Untuk tingkat SMK kurikulum 2013 ini juga memiliki keunggulan tersendiri dibanding dengan kurikulum sebelumnya, yaitu materi pada K-13 sudah mendekati dengan kebutuhan pasar tenaga kerja tingkat menengah.

\section{KESIMPULAN}

Berdasarkan hasil penelitian mengenai evaluasi implementasi kurikulum 2013 di tingkat sma/smk/ma sederajat di kabupaten pringsewu menggunakan model CIPP dapat disimpulkan implementasi kurikulum 2013 di tingkat sma/smk/ma sederajat di kabupaten 
pringsewu sudah berjalan dengan baik, tetapi beberapa aspek masih perlu penyempurnaan. Adapun Aspek yang belum optimal dan perlu ditingkatkan lagi adalah sarana prasarana, proses pembelajaran, dan proses penilaian.

\section{DAFTAR PUSTAKA}

Nasution. 2008. Kurikulum dan Pengajaran. Bandung:Bumi Aksara

Permendikbud. 2013. Peraturan Menteri Pendidikan dan Kebudayaan Nomor 67, Tahun 2013, tentang Kerangka Dasar dan Struktur Kurikulum.

Allan C. Ornstein dan Francis P. Hunkins. 2004. Curriculum: Foundation, Principles, And Issues, Fourth Edition. Boston USA: Pearson Education

Meiana Yurike Dewi. 2015. Implementasi Kurikulum 2013 Pada Mata Pelajaran Bahasa Indonesia di SMA Negeri Kabupaten Bantul Yogyakarta. Yogyakarta: UNY

Majid, A. 2014. Implementasi Kurikulum 2013 Kajian Teoritis dan Praktis. Bandung: Interes Media

Kunandar. 2013. Penilaian Autentik. Jakarta: Raja Grafindo Persada

Mendikbud. 2013. Dokumen Kurikulum 2013 (Draf). Jakarta: Kementerian Pendidikan dan Kebudayaan

Syaodih, N. 2009. Pengembangan Kurikulum. Bandung: PT Remaja Rosdakarya

Hasan, H. 2008. Evaluasi Kurikulum. Bandung: Rosda Karya

Nazir, M. 2009. Metode Penelitian. Bandung: Remaja Rosdakarya

Sugiyono.2007. Metode Penelitian Kuantitatif Kualitatif dan R\&D. Bandung;Alfabeta

Singarimbun, M., dan Sofian, E. 1989. Metode Penelitian Survai. Jakarta: LP3ES

Nazir, M. 2005. Metode Penelitian. Jakarta: Ghalia

Datuuk, D.A .2014. Manajemen Implementasi Kurikulum: Strategi Penguatan Implementasi Kurikulum 2013. Jurnal Cakrawala Pendidikan, Februari 2014, Th. XXXIII, No. 1

Abrory,M dan Kartowagiran, B. 2014. Evaluasi Implementasi Kurikulum 2013 pada Pembelajaran Matematika SMP Negeri Kelas VII di Kabupaten Sleman. Jurnal Evaluasi Pendidikan - Volume 2, No 1 